\title{
Dermoscopic features of Clear Cell Acanthoma: A Case Report and Review of the Literature
}

\author{
Moustaide K, Aqil N, Gallouj S and Mernissi FZ \\ Department of Dermatology, University Hassan II Hospital, Avenue Hassan II, Morocco
}

*Corresponding author: Moustaide K, Department of Dermatology, University Hassan II Hospital, Avenue Hassan II, Fes 30050, Morocco, Tel: 00212641796117; E-mail: kmoustaide@gmail.com

\begin{abstract}
Clear cell acanthoma is an uncommon type of benign epithelial tumor. Typically, it is a solitary lesion found on the lower limbs. It presents as a nodule or small plaque with slow and well-defined growth. Diagnosis used to be clinical and histopathological, but the advent of dermoscopy has led to an increase in diagnostic accuracy. We describe a case in which dermoscopy proved highly useful for diagnosis of the lesion.
\end{abstract}

Keywords: Acanthoma; Dermoscopy; Diagnostic imaging; Diagnosis

Received Date: April 12, 2019; Accepted Date: May 31, 2019; Published Date: June 07, 2019

\section{Introduction}

Clear-cell acanthoma (CCA), or Degos acanthoma, is a rare clinical entity first described by Degos and colleagues in 1962 [1]. Traditionally thought to be a form of benign epidermal neoplasia [2], CCA has also been suggested to be a form of nonspecific reactive dermatosis $([3,4]$ or localised psoriasis, in view of changes in the dermal microvasculature and immunohistochemical findings [3-6]. On histopathology CCA is characterized by a well-demarcated area of psoriasiform epidermal hyperplasia with keratinocytes with pale-staining cytoplasm. Mild spongiosis, exocytosis of neutrophils and thinning of the suprapapillary plates may also be evident [7].

CCA typically arises on the lower extremities, with a peak age of incidence of 60 years and both sexes are equally affected [8]. In most cases CCA presents as a solitary, slow growing pink, red or brown papule or nodule that is moist, wellcircumscribed and typically $3 \mathrm{~mm}-2 \mathrm{~cm}$ in diameter. The surface may resemble a vascular lesion such as pyogenic granuloma. Occasionally patients present with multiple lesions [9]. CCA is commonly mistaken for basal cell carcinoma, irritated seborrhoeic keratosis, squamous cell carcinoma, amelanotic melanoma or even psoriasis [8].

Dermoscopic recognition of CCA may help to avoid unnecessary biopsies or surgical excision. There are few reports on the dermoscopic features of CCA and we report a new descriptive case of dermoscopy of CCA in order to delineate the key dermoscopic features of CCA.

Citation: Moustaide K, Dermascopic features of Clear Cell Acanthoma: A Case Report and Review of the Literature. J Clin Cases Rep 2(4): 98-101. DOI: https://doi.org/10.46619/joccr.2019.2-1048 


\section{Case Report}

A 75-year-old woman presented with a red and flaky papule 5-year-old at the cheek (Figure 1). The lesion intermittently bleeds, did not respond to topical corticosteroids or cryotherapy and increased size. Dermatoscopy revealed red dots, globules and glomeruloid structures, are not linear, forming an incomplete vascular lattice pattern (Figure 2A and Figure 2B). A peripheral collarette of translucent scale was the only non-vascular feature of note.

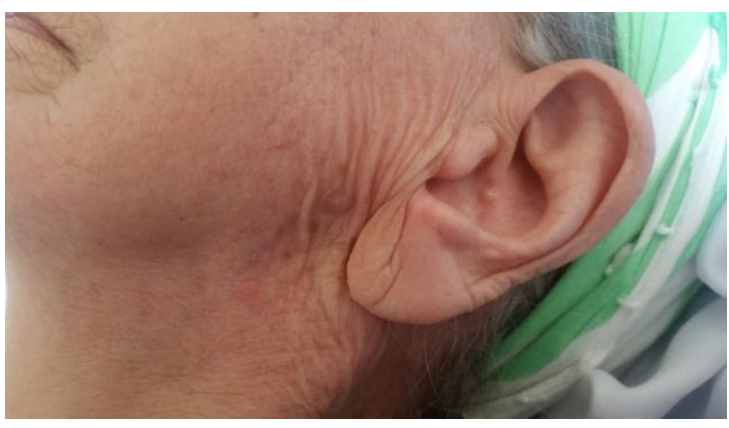

Figure 1: Clinical image
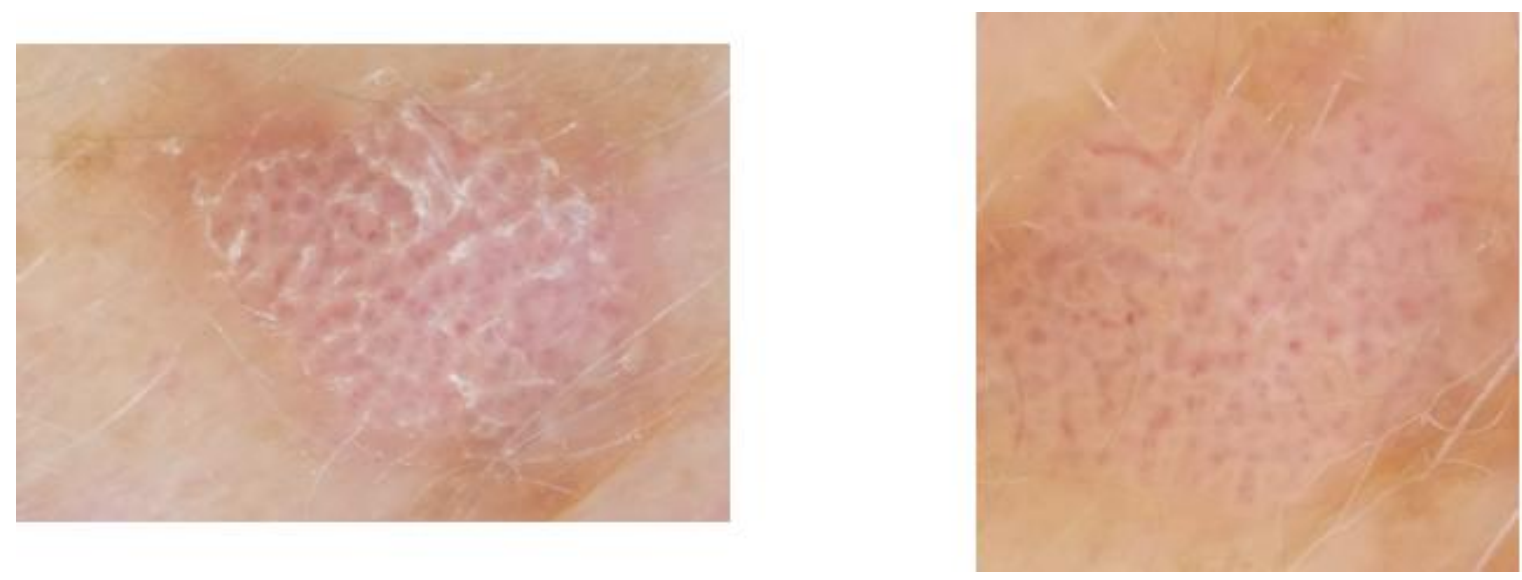

Figure 2: A) Dermoscopic images of the lesion with red pin-point and globular dots, some arranged in a linear or 'string-ofpearls' formation (long arrows) and B) A border of translucent scale (short arrows).

\section{Discussion}

Dermoscopy is a non-invasive, in vivo technique that relies on bright light-emitting diode illumination and magnification (usually $\times 10$ ) of skin lesions, exposing subsurface colours and structures that are not ordinarily visible to the naked eye. On dermoscopy CCA has a unique appearance, characterized by red dots, globules and, in some cases, glomeruloid vessels, at least some of which are arranged in linear or serpiginous patterns. These linear arrangements are reticular and strikingly symmetric when fully developed. In some cases the vascular reticular pattern is incomplete or partly developed, either representing a forme fruste or a compression artefact but still distinctly recognizable.

This vascular pattern is distinct from that of other lesions. Dotted or glomeruloid vessels can be a feature of inflammatory dermatoses, such as psoriasis, pityriasis lichenoides and discoid eczema [17-20]. However, in these conditions the red dots or glomeruloid vessels are uniformly distributed and do not coalesce to form linear or vascular reticular arrays [17-20]. Glomeruloid vessels can be seen on dermoscopy in Bowen's disease and red dots in dysplastic naevi, spitz naevi or melanomas 
http://www.tridhascholars.org | October-2019

[17,20-22]. In these tumours the vessels may be regularly spaced, grouped or irregularly arranged but they do not form the characteristic vascular reticular pattern seen in clear cell acanthoma [17,20-22].

Other dermoscopic features of CCA include the variable presence of areas of haemorrhage, orange crusts and a peripheral collarette of translucent scales. The frequent presence of crystalline structures when CCA is observed using polarised dermoscopy was also noted, a finding that has not been previously described in the literature. The largest and most significant study assessing for crystalline structures included 11,225 lesions (both melanocytic and non-melanocytic), but no clear cell acanthoma [23].

\section{Conclusion}

Clear cell acanthoma has a distinctive dermoscopic appearance, characterized by a complete or incomplete vascular reticular pattern that helps in reaching a confident clinical diagnosis and minimizing the need for biopsy.

\section{References}

1. Degos R, Delort J, Civatte J, et al. (1962) Epidermal tumor with an unusual appearance: clear cell acanthoma. In Annales de Dermatologie et de Syphiligraphie 89: 361-371.

2. Degos R, Civatte J (1970) Clear-cell Acanthoma* Experience of 8 Years. British Journal of Dermatology 83(2): 248254.

3. Zedek DC, Langel DJ, White WL (2007) Clear-cell acanthoma versus acanthosis: a psoriasiform reaction pattern lacking tricholemmal differentiation. The American Journal of Dermatopathology 29(4): 378-384.

4. Finch TM, Tan CY (2000) Clear cell acanthoma developing on a psoriatic plaque: further evidence of an inflammatory aetiology?. British Journal of Dermatology 142(4): 842-844.

5. Bugatti L, Filosa G, Broganelli P, et al. (2003) Psoriasis-like dermoscopic pattern of clear cell acanthoma. Journal of the European Academy of Dermatology and Venereology 17(4): 452-455.

6. InalÖz HS, Laidler P (1999) Is clear cell acanthoma a form of localised psoriasis?. British Journal of Dermatology 141(Supplement 55): 121.

7. Weedon D (2010) Weedon's Skin Pathology ( $3^{\text {rd }}$ Edn.). New York: Churchill Livingstone, USA.

8. Morrison LK, Duffey M, Janik M, et al. (2010) Report: Clear cell acanthoma: a rare clinical diagnosis prior to biopsy. International Journal of Dermatology 49(9): 1008-1011.

9. Trau H, Fisher BK, Schewach-Millet M (1980) Multiple clear cell acanthomas. Archives of Dermatology 116(4): 433434.

10. Akin FY, Ertam I, Ceylan C, et al. (2008) Clear cell acanthoma: new observations on dermatoscopy. Indian Journal of Dermatology, Venereology, and Leprology 74(3): 285-287.

11. Tanaka T, Arai T, Ishikawa T, et al. (2010) Pedunculated clear cell acanthoma. Report of a case with dermoscopic observation. European Journal of Dermatology 20(1): 132-133.

12. Karadağ Köse Ö, Durdu M, Okçu Heper A, et al. (2011) Value of the Tzanck smear test and dermatoscopy in the diagnosis of clear cell acanthoma. Clinical and Experimental Dermatology: Viewpoints in Dermatology 36(3): 314-315.

13. Ardigo M, Buffon RB, Scope A, et al. (2009) Comparing in vivo reflectance confocal microscopy, dermoscopy, and histology of clear-cell acanthoma. Dermatologic Surgery 35(6): 952-959. 
14. Zalaudek I, Hofmann-Wellenhof R, Argenziano G (2003) Dermoscopy of clear-cell acanthoma differs from dermoscopy of psoriasis. Dermatology 207(4): 428-428.

15. Blum A, Metzler G, Bauer J, et al. (2001) The dermatoscopic pattern of clear-cell acanthoma resembles psoriasis vulgaris. Dermatology 203(1): 50-52.

16. Lacarrubba F, De Pasquale R, Micali G (2003) Videodermatoscopy improves the clinical diagnostic accuracy of multiple clear cell acanthoma. European Journal of Dermatology 13(6): 596-598.

17. Pan Y, Chamberlain AJ, Bailey M, et al. (2008) Dermatoscopy aids in the diagnosis of the solitary red scaly patch or plaque-features distinguishing superficial basal cell carcinoma, intraepidermal carcinoma, and psoriasis. Journal of the American Academy of Dermatology 59(2): 268-274.

18. Vázquez-López F, Manjón-Haces JA, Maldonado-Seral C, et al. (2003) Dermoscopic features of plaque psoriasis and lichen planus: new observations. Dermatology 207(2): 151-156.

19. Argenziano G, Zalaudek I, Corona R, et al. (2004) Vascular structures in skin tumors: a dermoscopy study. Archives of Dermatology 140(12): 1485-1489.

20. Bowling J (2012) Diagnostic Dermatology: The Illustrated Guide. Oxford: Wiley-Blackwell, USA.

21. Martín JM, Bella-Navarro R, Jordá E (2012) Vascular patterns in dermoscopy. Actas Dermo-Sifiliográficas (English Edn.) 103(5): 357-375.

22. Soyer HP, Argenziano G, Hofmann-Wellenhof R, et al. (2012) Dermoscopy: The Essentials. Edinburgh: Saunders.

23. Balagula Y, Braun RP, Rabinovitz HS, et al. (2012) The significance of crystalline/chrysalis structures in the diagnosis of melanocytic and nonmelanocytic lesions. Journal of the American Academy of Dermatology 67(2): 194-e1-e8. 